\title{
Regional Language Prevention Socialization of Covid- 19 in Soropia District
}

\author{
La Ino $^{1 *}$, Lilik Rita Lindayani ${ }^{2}$, Syahrun $^{3}$, Aswati $^{4}$, La Ode Topo Jers ${ }^{5}$, Samsul $^{6}$, Maliudin ${ }^{7}$, \\ Wa Ode Halfian ${ }^{8}$ \\ Faculty of Cultural Science, Universitas Halu Oleo, Kendari-Sulawesi Tenggara, Indonesia
}

$\left\{\underline{\text { laino@uho.ac.id }}{ }^{1}\right\}$

\begin{abstract}
The very significant distribution of the Corona Virus Disease (Covid 19) continues to show an increase, thus stimulating the government's fast and precise work in its efforts to overcome it. Various ways have been carried out by the government, especially the Southeast Sulawesi provincial government, both in the nature of implementation in the field through spraying disinfectants, or through circulars and oral announcements related to Covid 19, including appeals to Work From Home and social distancing which is conveyed officially through YouTube recordings and letters circular. However, not a few people pay attention to this, which is shown by the many activities that involve many people. Therefore, efforts are needed that can be more effective from the government, including using persuasive actions by touching public awareness, one of which can be done through the local language. By using the local language approach, this service is carried out to raise public awareness of the importance of preventing the transmission of Covid 19 where the virus has caused deaths of up to $9 \%$, which is currently still increasing in number. In addition to regional languages, this service also targets people's understanding, especially youth, of foreign terms related to the Covid 19 pandemic, both in terms of health and social, food and economic sectors which are very close to everyday life but are still poorly understood by them. An understanding of these terms is important, given their inherent impact on the public profession.
\end{abstract}

Keywords: Local languages; Covid 19; Soropia District

\section{Introduction}

As we all know, Corona Virus Disease 2019 (COVID-19) has become an international pandemic. Coronavirus Pandemic has been announced by WHO, the World Health Organization on March 11, 2020. This means that countries around the world must respond to, prevent and deal with the Corona Virus Pandemic. The COVID-19 outbreak is a global pandemic that very

Unsettling Public (source: https://www.jogloabang.com). The potential for its rapid spread makes all the potential of the community obliged to work hand in hand to take precautions to minimize transmission. A single narrative from the central government that is continued by 
the regional government is not sufficient to raise public awareness, especially ordinary people in areas or those in rural areas.

As for the policies in the form of appeals or calls for social restrictions instructed by the government so far are not very effective due to the lack of public knowledge, social awareness accompanied by dilemmas on the economic resilience of the community caused by the problem of dissemination. the case of terminology or knowledge of new and foreign linguistic terms, this has the potential to create a new premise in society in heeding the government's call for the dangers of the pandemic. Lack of understanding of new / foreign terms causes the appeal to pass away, so that the public's preventive attitude towards this pandemic is nothing more than just panicking to the point of not caring at all.

\section{Method}

This Community Service activity will begin with socializing the Thematic KKN Integrated Lecturer Service Program to all prospective students participating in this service activity. In this socialization, the community service team which is the Thematic KKN Field Supervisor will convey the requirements that must be met by students who can become Thematic KKN participants. Participants who have met the requirements are then given a letter of willingness to take part in the Halu Oleo University Thematic KKN program in Soropia District. This preparation activity has previously gone through the location survey stage and the identification of problems in the sub-district so that the participants who meet the requirements will be provided with the achievement targets of the service activities to be carried out.

\section{Results and Discussion}

Socialization activities were carried out by door to door (house to house) with the aim of avoiding crowds, maintaining distance, and following health protocols in the midst of the Covid - 19 virus pandemic. This socialization activity was carried out using regional languages in accordance with the themes given by the Faculty and The university, in this case uses the Bajo language as the language used by the majority of people in Bajoe village with the aim of making it easier for the local community to understand.

\subsection{Implementation Activities}

Before conducting socialization activities, the Bajoe village real work team (KKN) team in the Soropia sub-district conducted a field survey to find out the real conditions of the community in that location. After conducting a field survey, the next step is to identify the problems that exist in the $\mathrm{KKN}$ location related to the impact and community efforts to prevent the spread of the Covid-19 virus.

Then after knowing and identifying the various problems that exist at the KKN location related to the impacts and efforts of the community in preventing the spread of the Covid-19 virus, the thematic KKN participants again identify but are related to public knowledge about preventing the transmission of the Covid -19 virus through government appeals, as well as information from the media and other means. 
After making various identifications related to problems regarding the prevention of transmission of the Covid-19 virus, then thematic KKN participants carried out the practice of making a good and correct handwashing tutorial video according to the standards of the World Health Organization (WHO) and making a video on how to use a good and correct mask. In addition to making videos, thematic KKN participants also made posters and pamphlets that were packaged in attractive designs and made in two languages, namely Bajo and Indonesian to make it easier for the public to understand various things related to preventing the transmission of the Covid -19 virus. This is made as a teaching aid when conducting socialization activities.

This activity was carried out with the aim of providing a better understanding to the public about the Covid-19 virus and how to prevent it. After various activities have been carried out, the next step is to disseminate the prevention of transmission of the Covid-19 virus which is carried out door to door, which aims to avoid crowds, maintain distance, and still pay attention to health protocols.

The activity of making hand washing facilities is an additional program that aims to help people wash their hands more diligently according to the standards of the World Health Organization (WHO) as part of the socialization of prevention of transmission of the Covid-19 virus and the application of clean and healthy living habits. This activity, which was carried out from July 7 to July 10, 2020, is expected to help increase public awareness of the importance of preventing the transmission of the Covid-19 virus and implementing clean and healthy living habits by diligently washing hands.

\subsection{Spraying Disinfectant Liquid}

This disinfectant spraying activity is also an additional program for thematic KKN participants. This activity, which was carried out from 11 to 12 July 2020, is expected to help the public avoid exposure to the Corona virus (Covid - 19). Before carrying out the spraying activity, the process of making disinfectant liquid is carried out first. The liquid is made by dissolving 10 bottle caps of the Wipol floor cleaner solution in 3 liters of water.

After the manufacturing process is complete, the next step is to spray the houses of approximately 147 residents covering three hamlets, namely Mapadakau hamlet, Sikamaseang hamlet and Samaturu hamlet. This activity was very welcomed by the community, considering their level of awareness of the dangers of the Corona virus (Covid - 19) was increasing after thematic KKN participants carried out socialization activities about Covid - 19 and how to prevent it.

We also conduct meetings on technical data collection in the community. The result of the meeting obtained was that the data collection process in the community was carried out in groups with 1 group consisting of 4 people. When conducting interviews, group members must use complete PPE, keep their distance, and the maximum number of interviewers is 2 people in one house. Then data retrieval is done in waves. The first group collects data on the ceiling of the day, the second group at noon and the next group collects data in the afternoon.

Mend design of an informative pamphlet regarding the symptoms of Covid 19, which contains the symptoms of Covid 19, the Call Center for the Handling of Covid 19 in the Southeast Sulawesi region is very important and is one of our work programs to then be able to go down the field to collect data and interviews about the public's understanding of Covid 19, such as the application of Physical Distancing and PPE when doing activities outside the home, as well as to find out whether the public continues to update information about Covid 19 and put up informative Covid 19 posters in people's homes. 
The next day continued with interviews to find out problems that had arisen in an effort to prevent Covid 19 in the economic sector. The questions raised relate to (1) the economic activities of the community during Covid, (2) whether the community has other sources of income besides being fishermen, and (3) whether there are BLT or basic necessities from the government to support community needs during the pandemic (Lockdown).

This activity was carried out by asking several questions related to PPE and local wisdom. After conducting several consultations with the supervisor to find out the intended local wisdom, we asked questions which included (1) was there any PPE assistance from the government during Covid 19, (2) was there any difficulty in accessing PPE in the blooming village, (3) ) do people in Mekar village have certain herbal ingredients that are believed to increase body resistance against Covid, (4) do people know how to make emergency PPE such as masks made of clean socks, tissues, or handkerchiefs and disinfectants using household materials such as floor cleaning fluid,

\section{Conclusion}

Outreach to the public regarding Covid - 19 door to door (house to house) with the aim of avoiding crowds and maintaining distance, Providing understanding to the public about how to prevent transmission of the Covid - 19 virus, Conducting socialization of clean and healthy living habits (PHBS) in the framework preventing transmission of the Covid - 19 virus, Creating interesting local language content in the form of posters and pamphlets containing prevention against transmission of the Covid - 19 virus, Making good and correct handwashing tutorial videos based on official standards of the World Health Organization (WHO) with the aim of providing awareness to the public in order to avoid the Covid-19 virus, Making a place to wash hands, Spraying disinfectants.

\section{References}

[1] Riewanto, Agus. 2020. PANDEMIC COVID-19 AND GOVERNMENT POLICY CONTROVERSION (PSBB, Civil Emergency \& Omnibus Law Bill Ciptaker). Paper presented in an online discussion held by BEM FH Universitas Sebelas Maret, on April 18, 2020.

[2] Suyanto, Bagong and Sutinah. 2015. Social Research Methods (Various Alternative Approaches). Yogyakarta: Kencana Prenada.

[3] Thompson, John B. 2014. Analysis of World Ideology (Discourse Point of IdeologyWorld Ideology) (Terj, Yakin, et al). Yogyakarta: IRCiSoD.

[4] Law No. 6 of 2018 Article 5 Paragraph (1) concerning Health Quarantine. Yuliana. 2020. Corona Virus Desease Icovid 19): A Literature Review.

[5] Wellness and Healthy Magazine: Vol. 2 No. February 1, 2020.

[6] https://www.liputan6.com/regional/read/4232706/warga-suku-bajo-jungkir-balikfight-to-survive-the-pandemic-covid-19. (accessed April 22, 2020)

[7] https: //www.jogloabang.com/k Kesehatan/pp-21-2020-social-social-scale-big-frameacceleration-handling-covid-19. (accessed April 22, 2020)

[8] https://setkab.go.id/inilah-pp-pemb Batas-social-berskala-besar-untuk-perc Speedhandling-covid-19/. ((accessed April 23, 2020) 
[9] Presidential Decree No.11 / 2020 concerning the Determination of the Covid-19 Community Emergency PP No.21/2020 Concerning PSBB

[10] Perppu No. 1/2020 Concerning State Financial Policy

[11] Presidential Instruction No.4 / 2020 concerning refocusing activities, budget reallocation of Covid-19 Permenkes No. 9/2020 concerning PSBB Guidelines

[12] Permendagri No. 20/2020 Regarding the Acceleration of Handling Covid-19 in the Local Government Instruction of the Minister of Home Affairs No.1 / 2020 Regarding the Prevention of the Spread of Covid-19 